\title{
Phosphodiesterase Type 5 Inhibitor Sildenafil Decreases the Proinflammatory Chemokine CXCL10 in Human Cardiomyocytes and in Subjects with Diabetic Cardiomyopathy
}

\author{
Luigi Di Luigi, ${ }^{1}$ Clarissa Corinaldesi, ${ }^{1}$ Marta Colletti, ${ }^{1}$ Sabino Scolletta, ${ }^{2}$ Cristina Antinozzi, ${ }^{1}$ \\ Gabriella B. Vannelli, ${ }^{3}$ Elisa Giannetta, ${ }^{4}$ Daniele Gianfrilli, ${ }^{4}$ Andrea M. Isidori, ${ }^{4}$ \\ Silvia Migliaccio, ${ }^{1}$ Noemi Poerio, ${ }^{5}$ Maurizio Fraziano, ${ }^{5}$ Andrea Lenzi, ${ }^{4}$ and Clara Crescioli ${ }^{1,6}$
}

\begin{abstract}
T helper 1 (Th1) type cytokines and chemokines are bioactive mediators in inflammation underling several diseases and co-morbid conditions, such as cardiovascular and metabolic disorders. Th1 chemokine CXCL10 participates in heart damage initiation/progression; cardioprotection has been recently associated with sildenafil, a type 5 phosphodiesterase inhibitor. We aimed to evaluate the effect of sildenafil on CXCL10 in inflammatory conditions associated with diabetic cardiomyopathy. We analyzed: CXCL10 gene and protein in human cardiac, endothelial, and immune cells challenged by pro-inflammatory stimuli with and without sildenafil; serum CXCL10 in diabetic subjects at cardiomyopathy onset, before and after 3 months of treatment with sildenafil vs. placebo. Sildenafil significantly decreased CXCL10 protein secretion $\left(\mathrm{IC}_{50}=2.6 \times 10^{-7}\right.$ ) and gene expression in human cardiomyocytes and significantly decreased circulating CXCL10 in subjects with chemokine basal level $\geq 930 \mathrm{pg} / \mathrm{ml}$, the cut-off value as assessed by ROC analysis. In conclusion, sildenafil could be a pharmacologic tool to control CXCL10-associated inflammation in diabetic cardiomyopathy.
\end{abstract}

KEY WORDS: inflammation; T helper 1; cardiomyopathy; CXCL10; PDE5 inhibition.

\section{INTRODUCTION}

Nowadays, there is growing evidence on a tight association between cardiac dysfunction and $\mathrm{T}$ helper (Th)1-driven inflammation [1-3], with the specific involvement of some

Luigi Di Luigi, Clarissa Corinaldesi and Marta Colletti contributed equally to this work.

Electronic supplementary material The online version of this article (doi:10.1007/s10753-016-0359-6) contains supplementary material, which is available to authorized users.

${ }^{1}$ Department of Movement, Human and Health Sciences, University of Rome "Foro Italico", Rome, Italy

${ }^{2}$ Department of Medical Biotechnologies, Anesthesia and Intensive Care, University of Siena, Siena, Italy

${ }^{3}$ Department of Experimental and Clinical Medicine, University of Florence, Florence, Italy cytokines and chemokines, such as tumor necrosis factor (TNF) $\alpha$, monocyte chemoattractant protein (MCP)-1 or CCL2, macrophage inflammatory protein (MIP) $1-\beta$ or CCL4, interferon (IFN)- $\gamma$-inducible protein-10, IP-10 or CXCL10, interleukin (IL)-8 or CXCL8, IL-1 $\beta$, IL-6, IL-12, IL-23 [2, 4-11].

\footnotetext{
${ }^{4}$ Department of Experimental Medicine, Sapienza University of Rome, Rome, Italy

${ }^{5}$ Department of Biology, University of Rome "Tor Vergata", Rome, Italy

${ }^{6}$ To whom correspondence should be addressed at Department of Movement, Human and Health Sciences, University of Rome "Foro Italico", Rome, Italy. E-mail: clara.crescioli@uniroma4.it
}

Abbreviations: BMI, Body mass index; HOMA, Homeostatic model assessment; HbA1c, Glycated hemoglobin; BP, Blood pressure; LVMi, Left ventricular mass index; EDVi, End-diastolic volume index 
In particular, the chemokine CXCL10 has been shown to play a pivotal role in early Th1-driven processes underlying heart damage initiation and progression, i.e., during cardiac transplantation, myocarditis, and cardiopulmonary bypass [12-17]. The level of pretransplant serum CXCL10 is a predictive biomarker of cardiac damage and acute organ rejection in heart transplant recipients [12]; furthermore, CXCL10 can be induced and released by human cardiac cells under inflammatory challenge and likely contributes to establish and maintain a selfinflammatory loop between blood and local tissues [1216]. This small chemokine is, indeed, one of the major trigger of activation and polarization of Th1 inflammatory response both at systemic and tissue level [12, 13, 18-20].

It is quite a recent acquisition that some Th1-driven processes can be counteracted by the inhibitors of phosphodiesterase type 5 (PDE5i) [21]. This class of drugs, which includes sildenafil, vardenafil, tadalafil, and avanafil, is widely used as on-demand treatment for erectile dysfunction (ED) because of the significant vasodilatory effect achieved through PDE5 inhibition and cyclic guanosine monophosphate (cGMP) stabilization in vascular beds [22-27]. In view of those vasoactive effects, PDE5 inhibition has been hypothesized as a therapeutic approach for a number of cardiovascular disturbances as well. Sildenafil, in particular, has been shown to exert cardioprotective effects after ischemia/reperfusion injuries, reduce infarct size or ventricular arrhythmias [24, 28, 29], ameliorate heart failure (HF) patients with reduced ejection fraction $(\mathrm{EF})$, and improve cardiac functional capacity and geometry in subjects with diabetic cardiomyopathy [30, 31]. Interestingly, studies on effectiveness show that sildenafil retains better cardiovascular profile vs. the other PDE5i [32]. Thus, sildenafil seems a good candidate to be a therapeutic tool in cardiovascular medicine [25].

It is well-known that vascular bed is the "standard" target of PDE5i [33, 34].

The purpose of this study is to verify whether sildenafil could target CXCL10 in human cardiomyocytes challenged by Th1-type-inflammatory stimuli; IL-6 and IL-8, both involved in inflammation and cell damage in cardiac disease $[35,36]$, have been also investigated. Methylprednisolone (MeP), cyclosporine (CsA), and mycophenolate (MPA) were used for comparison. We also analyzed the effect of sildenafil onto CXCL10 in human endothelial and different subtypes of immune cells (human PBMC, monocytes, macrophages) in the same experimental conditions. Furthermore, we aimed to investigate circulating level of CXCL10 in subjects with diabetic cardiomyopathy, a Th1-driven comorbid condition, before and after 3 months sildenafil intake vs. placebo.

\section{MATERIALS AND METHODS}

\section{Chemicals}

Dulbecco modified eagle medium (DMEM)/Ham's F-12 medium (1:1) with and without phenol red, RPMI 1640, phosphate buffered saline $\mathrm{Ca}^{2+} / \mathrm{Mg}^{2+}$-free (PBS), bovine serum albumin (BSA) fraction $\mathrm{V}$, antibiotics, $\mathrm{NaOH}$, EDTA-trypsin solution, Bradford reagent, methylprednisolone (MeP), cyclosporine A (CsA) and mycophenolic acid (MPA), phytohemagglutinin (PHA), PDE5 inhibitor sildenafil citrate salt, PDE4 inhibitor rolipram, PDE3 inhibitor cilostamide, PDE2 inhibitor erythro-9-(2-hydroxy-3-nonyl)adenine (EHNA), lipopolysaccharides (LPS) from Escherichia coli 0111:B4 were from Sigma-Aldrich Corp. (St. Louis, MO, USA). EGMTM Endothelial Growth Medium \& EGM ${ }^{\text {TM }}$ BulletKit ${ }^{\mathrm{TM}}$ were from Lonza; fetal bovine serum (FBS) and fetal calf serum (FCS) were from Hyclone (Logan, UT, USA). Recombinant Human IFN- $\gamma$ and recombinant Human TNF- $\alpha$ were from Peprotech ${ }^{\circledR}$ (RockyHill, NJ, USA). L-glutamine was from Gibco Laboratories (Grand Island, NY). Granulocytemacrophage colony-stimulating factor (GM)-CSF, ELISA kit for CXCL10, IL-8, and IL-6 measurement were from R\&D Systems (Minneapolis, MN, USA). For RNA extraction, TRIzol RNA isolation reagent was purchased by Ambion TM; for reverse transcription $10 \mathrm{mM}$ dNTP mix, random primers, RNaseOUTTM Ribonuclease inhibitor and SuperScript ${ }^{\circledR}$ III Reverse were purchased from Invitrogen. SYBR ${ }^{\circledR}$ Green PCR Master Mix for qPCR was from Life Technologies ${ }^{\mathrm{TM}}$ (Applied Biosystems $\left.{ }^{\circledR}\right)$. Ficoll-Paque PLUS was from Amersham Bioscences (Little Chalfont, UK). Trypan blue $0.5 \%$ was from Euroclone ${ }^{\circledR}(\mathrm{UK})$. Plastic ware for cell cultures and disposable filtration units for growth media preparation were purchase from Corning (Milan, Italy). Polyclonal rabbit anti-PDE5 and monoclonal mouse anti- $\beta$-actin were from Santa Cruz (CA, USA). All reagents for SDS-PAGE were from Millipore (Billerica, MA, USA). AutoMACS ${ }^{\circledR}$ Rinsing Solution, MACS ${ }^{\circledR}$ BSA Stock Solution, MicroBeads conjugated to monoclonal anti-human CD14 antibodies (isotype: mouse IgG2a), LS MACS ${ }^{\circledR}$ columns, and MidiMACS ${ }^{\circledR}$ separator were from Miltenyi Biotec (Bergisch Gladbach, Germany). Fluorochrome-conjugated CD14 antibody for flow cytometric analysis (CD14-FITC), Fluorescence-activated cell sorting (FACS) Calibur and CellQuest software for data analysis were from Becton Dickinson (Vienna, Austria). 


\section{Cell Cultures}

Human fetal cardiomyocytes (Hfcm) and human fetal aortic endothelial cells (Hfaec) were obtained from cardiac tissues or aortic ascendant tracts collected after voluntary abortion (10-12 weeks of gestation) characterized and maintained as described elsewhere [15, 20]. Legal abortions were performed in authorized hospitals, and certificates of consent were obtained. The use of human fetal tissue for research purposes conforms with the principles outlined in the Declaration of Helsinki and was approved by the committee for investigation in humans of the Azienda Ospedaliero-Universitaria Careggi, Florence, Italy (protocol no. 6783-04).

Peripheral blood mononuclear cells (PBMC) were isolated from buffy coats obtained from healthy adult anonymous donors in accordance with local ethical committee; approval by Azienda Policlinico Umberto I Rome Italy, accordance with the principles outlines in the Declaration of Helsinki and written consents were obtained. Briefly, heparinized blood, collected from peripheral vein, was centrifuged on Ficoll-Hystopaque gradient following manufacture's protocol. PBMC were cultured in RPMI supplemented with $10 \%$ FBS, 2 mmol/1 L-glutamine and antibiotics.

Monocytes were purified from total PBMC by negative selection using antibodies conjugated to magnetic beads and cultured in RPMI supplemented with $10 \%$ FBS, $2 \mathrm{mmol} / \mathrm{l} \mathrm{L}$-glutamine and antibiotics. After isolation, $2 \times 10^{6}$ cells were washed twice with PBS and stained with FITC-conjugated anti-CD14 for $30 \mathrm{~min}$. After two washing steps, cells were analyzed on a flow cytometer. Cell population purity (85-90\%) was assessed by sorting the CD14-positive $\left(\mathrm{CD} 14^{+}\right)$cells. Macrophages were obtained from highly purified $\mathrm{CD} 14^{+}$peripheral blood monocytes seeded onto 96-well round bottom plates in their growth medium and treated for 5 days with (GM)-CSF (35 ng/ml). Cell cultures in their specific growth medium were maintained in a fully humidified atmosphere of $95 \%$ air and $5 \%$ $\mathrm{CO}_{2}$.

\section{Subjects}

Frozen samples from 30 subjects with diabetic cardiomyopathy (DCM) enrolled and described in a previous study were analyzed (Clinical Trial Registration-URL: http://www.clinicaltrials.gov. Unique identifier: NCT00692237) [31]. The protocol was approved by Hospital Ethics Committee Policlinico Umberto I-Sapienza University Hospital of Rome, and written informed consent was obtained. This was a randomized controlled trial with patients allocated to receive $100 \mathrm{mg} /$ day sildenafil for 3 months or placebo [31]. A brief description of the protocol is here reported. Eligible men with type 2 diabetes were recruited from the outpatient of Policlinico Umberto I-Sapienza University Hospital of Rome, the inclusion criteria were: age 35-75 years; T2DM $>1$ year; glycated hemoglobin $(\mathrm{HbA} 1 \mathrm{c})<10 \%$; normal blood pressure (BP) or treated hypertension with achievement of a target of $\leq 130 / 80 \mathrm{mmHg}$; BMI $<40$. The exclusion criteria were: use of exogenous insulin, thiazolidinediones, or spironolactone; prior or current use of PDE5i; substance abuse; history of cardiovascular disease, proliferative retinopathy, autonomic neuropathy; symptoms or signs of ischemic heart disease during cardiac evaluations at enrollment; contraindications to sildenafil use or CMR imaging. Concomitant medications (anti-hypertensives, statins, oral anti-diabetics, etc.) were not changed between the months prior to the study and 1 month after its completion. All blood samples were collected from peripheral vein and serum was obtained by centrifugation $(3,000 \mathrm{rpm}$ for $10 \mathrm{~min}$ at $4{ }^{\circ} \mathrm{C}$ ); aliquots were stored at $-80{ }^{\circ} \mathrm{C}$ until analyzed. Analysis was performed on the active arm of the trial (sildenafil treatment).

Two additional groups of subjects, matched for sex and age, were analyzed for comparisons: eight subjects affected by diabetes without signs of cardiac impairment (DM) and eight subjects without diabetes, but with cardiac hypertrophy (IC). Characteristics of baseline the study population are reported in Table 1. Written informed consent was collected for all subjects.

\section{Cytokine Secretion Assay}

For CXCL10 secretion assay in Hfcm and Hfaec and for IL-8 and IL-6 assay in Hfcm, 4,000 cells/well were seeded onto 96-well flat bottom plates and maintained for $24 \mathrm{~h}$ in DMEM/Ham's F-12 medium (1:1) $10 \%$ FBS or Endothelial Growth Medium (EGM ${ }^{\mathrm{TM}}$ ), respectively. After overnight starvation (medium without serum and without phenol red), cells were stimulated for $24 \mathrm{~h}$ with IFN $\gamma$ $(1,000 \mathrm{U} / \mathrm{ml})+\mathrm{TNF} \alpha(10 \mathrm{ng} / \mathrm{ml})$ with or without sildenafil (1 $\mu \mathrm{M}), \mathrm{MeP}(250 \mathrm{ng} / \mathrm{ml}), \mathrm{CsA}(250 \mathrm{ng} / \mathrm{ml})$, or MPA $(26 \mu \mathrm{g} / \mathrm{ml})$ in serum free medium with $0.1 \%$ BSA. Cells in serum-free medium containing $0.1 \% \mathrm{BSA}$ and vehicle were used as control. PBMC, 200,000 cells/well, were seeded onto 96-well round bottom plates in their growth medium and stimulated for $48 \mathrm{~h}$ with $2 \%$ PHA with or without sildenafil $(1 \mu \mathrm{M}), \mathrm{MeP}(250 \mathrm{ng} / \mathrm{ml}), \mathrm{CsA}(250 \mathrm{ng} /$ $\mathrm{ml})$, or MPA $(26 \mu \mathrm{g} / \mathrm{ml})$ in RPMI supplemented with $10 \%$ FBS, $2 \mathrm{mmol} / \mathrm{l} \mathrm{L-glutamine}$ and antibiotics. Monocytes 
Table 1. Metabolic and Clinical Characteristics of the Study Populations

\begin{tabular}{|c|c|c|c|c|}
\hline Variable & $\begin{array}{l}\text { Diabetic cardiomyopathy } \\
\text { sildenafil } \mathrm{arm}^{\mathrm{a}}\end{array}$ & $\begin{array}{l}\text { Diabetic cardiomyopathy } \\
\text { placebo arm }\end{array}$ & $\begin{array}{l}\text { Diabetes mellitus without } \\
\text { cardiomyopathy }\end{array}$ & $\begin{array}{l}\text { Non diabetic hypertensive } \\
\text { cardiomyopathy }\end{array}$ \\
\hline Numbers & 30 & 16 & 8 & 8 \\
\hline Age (years) & $61.26 \pm 1.42$ & $60.72 \pm 1.33$ & $62.65 \pm 4.29$ & $63.40 \pm 4.10$ \\
\hline BMI $\left(\mathrm{kg} / \mathrm{m}^{2}\right)$ & $28.41 \pm 0.89$ & $27.60 \pm 0.85$ & $27.38 \pm 1.23$ & $25.77 \pm 1.31 *$ \\
\hline Glycemia $(\mathrm{mmol} / \mathrm{L})$ & $8.38 \pm 1.96$ & $8.18 \pm 1.56$ & $7.98 \pm 1.65$ & $5.08 \pm 0.65^{*}$ \\
\hline HOMA-index & $6.31 \pm 0.78$ & $7.55 \pm 0.84$ & $7.98 \pm 0.52$ & $5.08 \pm 0.21^{*}$ \\
\hline HbAlc (\%) & $7.95 \pm 0.23$ & $7.33 \pm 0.27$ & $6.90 \pm 0.49$ & $5.85 \pm 0.11^{*}$ \\
\hline $\begin{array}{l}\text { Mean systolic BP } \\
\quad(\mathrm{mmHg})\end{array}$ & $136.11 \pm 2.21$ & $131.45 \pm 2.85$ & $129.14 \pm 3.64$ & $138.87 \pm 3.96$ \\
\hline $\begin{array}{l}\text { Mean diastolic BP } \\
(\mathrm{mmHg})\end{array}$ & $79.66 \pm 1.60$ & $78.94 \pm 1.43$ & $77.68 \pm 1.40$ & $81.75 \pm 2.32$ \\
\hline $\operatorname{LVMi}\left(\mathrm{g} / \mathrm{m}^{2}\right)$ & $124.60 \pm 4.75$ & $114.15 \pm 5.96$ & $88.62 \pm 7.69 \dagger$ & $110.68 \pm 8.55$ \\
\hline $\operatorname{EDVi}\left(\mathrm{mL} / \mathrm{m}^{2}\right)$ & $61.36 \pm 1.74$ & $60.76 \pm 2.29$ & $64.26 \pm 4.11$ & $59.16 \pm 4.15$ \\
\hline $\begin{array}{l}\text { Ejection fraction } \\
\quad(\%)\end{array}$ & $61.59 \pm 1.52$ & $59.11 \pm 1.90$ & $66.80 \pm 1.81$ & $63.12 \pm 2.75$ \\
\hline NT proBNP (pg/ml) & $70.00 \pm 11.88$ & $72.23 \pm 18.52$ & $66.38 \pm 4.69$ & $81.73 \pm 10.90$ \\
\hline
\end{tabular}

Values are expressed as mean \pm SEM

${ }^{a}$ All subjects (responders and no-responders)

$* P<0.05$ (IC vs. DM), $\uparrow P<0.05$ (DCM vs. DM)

and macrophages, 200,000 cells/well, were seeded onto 96-well round bottom plates in their growth medium and stimulated for $48 \mathrm{~h}$ with LPS $(200 \mathrm{ng} / \mathrm{ml})$ with or without sildenafil $(1 \mu \mathrm{M}), \mathrm{MeP}(250 \mathrm{ng} / \mathrm{ml})$, CsA $(250 \mathrm{ng} / \mathrm{ml})$, or MPA $(26 \mu \mathrm{g} / \mathrm{ml})$ in RPMI supplemented with $10 \% \mathrm{FBS}$, $2 \mathrm{mmol} / \mathrm{l} \mathrm{L}$-glutamine and antibiotics.

Cells in growth medium with vehicle were used as control. The drug concentrations were selected based on their near-therapeutic doses, according to their pharmacokinetics (Cmax and area under the time concentration curves, AUC).

For dose-response assays, Hfcm, after overnight starvation, were incubated for $24 \mathrm{~h}$ with $\operatorname{IFN} \gamma(1,000 \mathrm{U} /$ $\mathrm{ml})+\mathrm{TNF} \alpha(10 \mathrm{ng} / \mathrm{ml})$ with or without sildenafil $(1 \times$ $10^{-7}, 2.5 \times 10^{-7}, 5 \times 10^{-7}, 1 \times 10^{-6}, 2.5 \times 10^{-6}, 5 \times 10^{-6}$, $\left.1 \times 10^{-5}, 2,5 \times 10^{-5} \mathrm{M}\right)$ or MPA $\left(8.1 \times 10^{-7}, 4.1 \times 10^{-6}\right.$, $8.1 \times 10^{-6}, 2.05 \times 10^{-5}, 4.1 \times 10^{-5}, 8.1 \times 10^{-5}, 1.6 \times 10^{-4}$, $\left.3.2 \times 10^{-4} \mathrm{M}\right)$.

For assays with different specific inhibitors of PDE subtypes, Hfcm were seeded, maintained, and starved in the same conditions as described above. Cells were treated for $24 \mathrm{~h}$ with IFN $\gamma(1000 \mathrm{U} / \mathrm{ml})+\mathrm{TNF} \alpha(10 \mathrm{ng} / \mathrm{ml})$ with or without sildenafil $(1 \mu \mathrm{M})$, rolipram $(10 \mu \mathrm{M})$, cilostamide $(1 \mu \mathrm{M})$, EHNA $(10 \mu \mathrm{M})$, in serum free medium with $0.1 \%$ BSA. Cells in serum-free medium containing $0.1 \%$ BSA and vehicle were used as control.

Supernatants from each experimental setting were harvested, centrifuged, and stored to $-20^{\circ} \mathrm{C}$ until performing ELISA. All experiments were performed in triplicate with at least four different cells preparations.

\section{ELISA Assays}

CXCL10, IL-8, and IL-6 levels were measured in cell culture supernatants using commercially available kits, according to the manufacturer's recommendations.

The sensitivity ranged from 0.41 to $4.46 \mathrm{pg} / \mathrm{ml}$ for CXCL10, less than $0.70 \mathrm{pg} / \mathrm{ml}$ for IL-6, from 1.5 to $7.5 \mathrm{pg} /$ $\mathrm{ml}$ for IL-8. The intra- and inter-assay coefficients of variation were: 3.1 and $6.7 \%$ for CXCL10, 4.4 and $3.7 \%$ for IL-6, 4.6 and $8.1 \%$ for IL-8. Quality control pools of low, normal, and high concentrations for all parameters were included in each assay. Protein measurement to normalize the amount of secreted cytokines was performed as reported elsewhere [19]. Data were expressed as percent of inhibition, calculated on IFN $\gamma+\mathrm{TNF} \alpha-$, PHAor LPS-induced release, taken as $100 \%$.

\section{Western Blot Analysis}

For protein analysis, $\mathrm{Hfcm}$ and $\mathrm{Hfaec}$ were seeded and maintained in the same conditions as previously reported [15, 20]. For PBMC and monocytes/macrophages protein analysis, $3 \times 10^{6}$ cells were seeded onto $100-\mathrm{mm}$ dishes or $25-\mathrm{cm}^{2}$ cell cultures flask, respectively, and maintained in RPMI 1640 medium. Protein concentration measurement was performed with Bradford Reagent. Protein aliquots $(20 \mu \mathrm{g})$ were processed, loaded onto $10 \%$ SDS-PAGE, transferred on nitrocellulose membranes, and incubated with primary Abs appropriately diluted in Tween Tris-buffered saline (TTBS; for anti- 

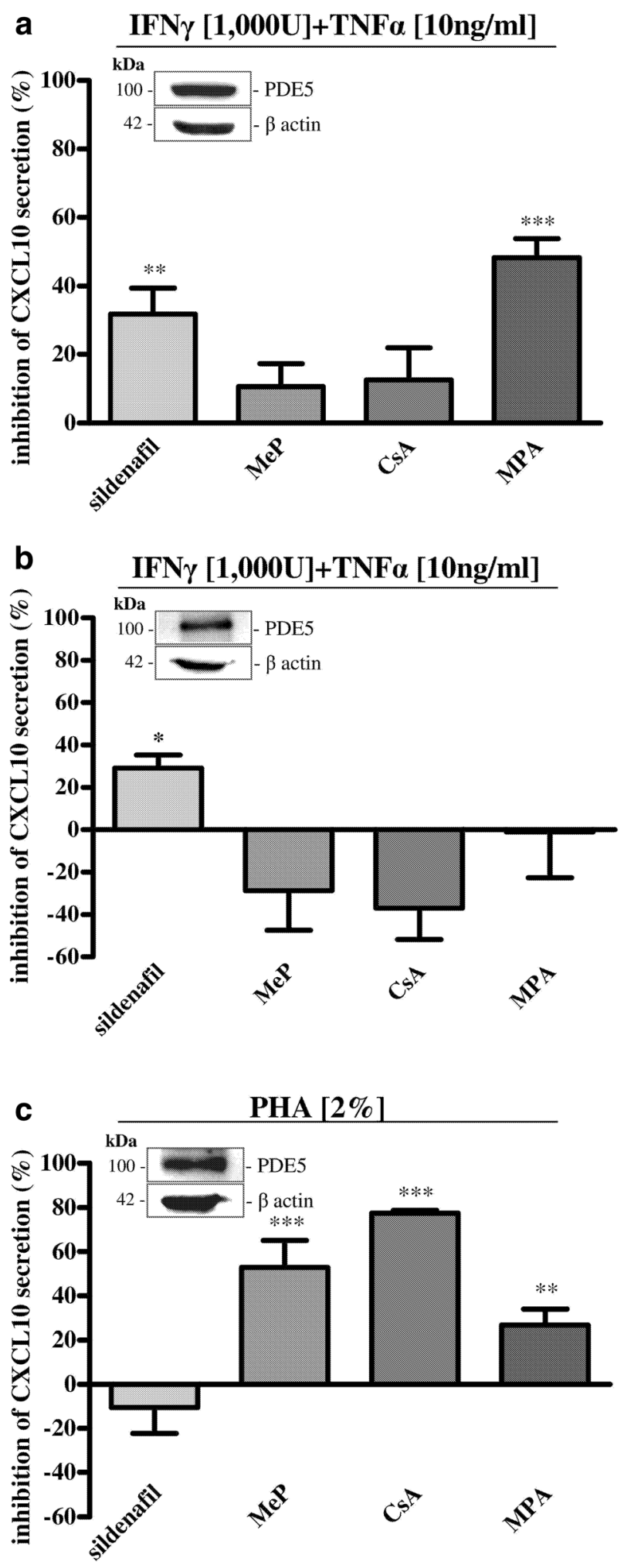

Fig. 1. Effect of sildenafil on cytokine-induced CXCL10 secretion in human cells in comparison with different immunosuppressors. a In $\mathrm{Hfcm}$, a significant inhibition of IFN $\gamma+\mathrm{TNF} \alpha$-induced CXCL10 protein secretion has been observed after 24-h incubation with sildenafil or MPA (31.8 \pm 7.6 and $48.3 \pm 5.5 \%$ inhibition, respectively; $* * P<0.01 ; * * * P<0.001$ ); no effect has been observed in presence of MeP or CsA. b Cytokineinduced CXCL10 protein secretion by Hfaec has been significantly reduced by sildenafil after $24 \mathrm{~h}\left({ }^{*} P<0.05 ; 29.1 \pm 6.3 \%\right.$ inhibition $)$ while no effect has been achieved in presence of the other drugs. $\mathbf{c}$ Sildenafil did not affect CXCL10 release by PHA-activated PBMC after $48 \mathrm{~h}$, whereas MeP, CsA and MPA exerted a significant inhibition (MeP: $52.8 \pm 12.4 \%$, CsA: $77.5 \pm 1.2 \%$, MPA: $26.80 \pm 7.2 \%$ inhibition; $* * * P<0.001$ and $\left.{ }^{* *} P<0.01\right)$. PDE5 protein expression has been detected by western blot in all three cell types investigated (inset of $\mathbf{a}, \mathbf{b}$, and $\mathbf{c}$ ). Results (mean \pm $\mathrm{SE}$ ) are expressed as inhibition of CXCL10 secretion percent of IFN $\gamma+$ $\mathrm{TNF} \alpha$ - or PHA-induced release, taken as $100 \%$. Data are obtained from four to nine experiments using different cell preparations.

PDE5 and anti- $\beta$-actin 1:1,000), followed by peroxidaseconjugated secondary $\operatorname{IgG}(1: 10,000)$. Proteins were revealed by the enhanced chemiluminescence system (ECL plus; Millipore). Image acquisition was performed with Image Quant Las 4000 software (GE Healthcare). Western blot analysis was performed for three/four independent experiments with different cell preparations.

\section{RNA Extraction, Reverse Transcription and Real-Time Quantitative PCR}

For mRNA analysis: $35,000 \mathrm{Hfcm}$ or Hfaec were seeded in 35-mm culture dishes and maintained for $24 \mathrm{~h}$ in their growth medium; after 12-h starvation (medium without serum and without phenol red), cells were stimulated for $24 \mathrm{~h}$ with a combination of IFN $\gamma(1,000 \mathrm{U} / \mathrm{ml})+\mathrm{TNF} \alpha$ $(10 \mathrm{ng} / \mathrm{ml})$ with or without sildenafil $(1 \mu \mathrm{M}), \mathrm{MeP}$ $(250 \mathrm{ng} / \mathrm{ml})$, CsA $(250 \mathrm{ng} / \mathrm{ml})$, or MPA $(26 \mu \mathrm{g} / \mathrm{ml})$ in serum-free medium with $0.1 \%$ BSA, cells in serum-free medium containing $0.1 \%$ BSA and vehicle were used as control; 200,000 PBMC were seeded onto 96-well round bottom plates in their growth medium and stimulated for $48 \mathrm{~h}$ with $2 \%$ PHA with or without sildenafil $(1 \mu \mathrm{M})$, MeP $(250 \mathrm{ng} / \mathrm{ml}), \mathrm{CsA}(250 \mathrm{ng} / \mathrm{ml})$, or MPA (26 $\mu \mathrm{g} / \mathrm{ml})$, cells in growth medium and vehicle were used s control. Total RNA was extracted from cultured cells using TRIzol ${ }^{\circledR}$ RNA Isolation Reagents $\left(\mathrm{Ambion}^{\mathrm{TM}}\right)$ according to the manufacturer's instructions. Single-stranded cDNA was obtained by reverse transcription of $1 \mu \mathrm{g}$ of total RNA. RT-qPCRs were performed using 7500 Real Time System (Applied Biosystems $^{\circledR}$ ) with SYBR-green fluorophore; $40 \mathrm{ng}$ of cDNA were used as template and cycling parameters were $95^{\circ} \mathrm{C}$ for $10 \mathrm{~min}$, followed by 40 cycles of $15 \mathrm{~s}$ at $95^{\circ} \mathrm{C}$, $1 \mathrm{~min}$ at $60^{\circ} \mathrm{C}, 30 \mathrm{~s}$ at $95{ }^{\circ} \mathrm{C}, 15 \mathrm{~s}$ at $60^{\circ} \mathrm{C}$. Fluorescence 
intensities were analyzed using the manufacturer's software (7500 Software v2.05) and relative amounts were obtained using the $2^{-\Delta \Delta \mathrm{Ct}}$ method and normalized for the $\beta$-actin. Data are expressed as fold increase vs. IFN $\gamma+\mathrm{TNF} \alpha$ - or PHA-induced expression taken as 1. Primers for CXCL10 were: forward (TTCCTGCAAGCCAATTTTGT) and reverse (ATGGCCTTCGATTCTGGATT); for $\beta$-actin, forward (CTGAACCCCAAGGCCAAC) and reverse (AGCCTGGATAGCAACGTACA).

\section{Cell Viability}

For cell viability assays: Hfcm and Hfaec (4,000 cells/well) were seeded in 96-well plates, maintained in phenol red- and serum-free medium overnight and incubated in serum-free medium containing $0.1 \%$ BSA with sildenafil $(1 \mu \mathrm{M})$ for $24-48 \mathrm{~h}$; cells in serum-free medium containing $0.1 \%$ BSA and vehicle were used as control.

PBMC $(150,000$ cells/well) were seeded in 96well plates in their growth medium and stimulated with PHA $(2 \%)$ with or without sildenafil $(1 \mu \mathrm{M})$ for 24 $48 \mathrm{~h}$. Control cells were in growth medium with vehicle and PHA. In each cell type, sildenafil was added each day. Cell viability was assessed each day by trypan blue $(0.05 \% v / v$ solution in PBS) exclusion, mixed in a ratio of $1: 1$. Cell number counting was assayed by hemocytometer; only cells that excluded trypan blue dye were included in the analysis. The number of viable cells at each time point was derived averaging at least five different fields for each well and each experimental point was repeated in duplicate or triplicate. Results are expressed as percent of cells at time zero (time of seeding). Experiments were performed four times with different cell preparations.

\section{Serum CXCL10 Assay}

Serum levels of CXCL10 were measured using a magnetic bead-based multiplex assay (Bio-Plex Pro ${ }^{\mathrm{TM}}$ Human Cytokine, Chemokine and Growth factor assay, Bio-Rad laboratories, Inc.) according to the manufacturer's protocol. A broad sensitivity range of standards (between 1.95 and 95,000 pg/ml; Bio-Rad Laboratories, Inc.) was used to enable the quantization of a dynamic wide range of cytokine concentrations and provide the greatest sensitivity. Data acquisition was performed by Bio-Plex 200 System $^{\text {TM }}$ (Bio-Rad Laboratories, Inc.) which uses Luminex fluorescent-bead-based technology (Luminex) with a flowbased dual laser detector with real-time digital signal processing to facilitate the analysis of up to 100 different families of color-coded polystyrene beads and allow multiple measurements of the sample ensuing in the effective quantification of cytokines. Data analysis was performed by BioPlex Manager ${ }^{\mathrm{TM}} 6.0$ software (Bio-Rad Laboratories, Inc.). Serum samples were run in triplicate at least twice.

\section{Statistical Analysis}

The statistical analysis was performed using 11.5 SPSS (SPSS Inc, Chicago, IL, USA). The KolmogorovSmirnov test was used to test for normal distribution of the data. Continuous data were compared using unpaired Student's $t$ test or Mann-Whitney test when appropriate. Binomial data were compared using chi-square analysis and Fisher's exact test when appropriate. Receiver operating characteristic (ROC) curve was constructed to identify the best predictive CXCL10 threshold (cut-off value) capable of discriminating between responders and non-responders to sildenafil administration. Briefly, ROC curve gives a graphic representation of the relationship between truepositive fraction (sensitivity, Se) and false-positive fraction

Table 2. CXCL10 Gene Expression in Human Cardiac, Endothelial, and Immune Cells

\begin{tabular}{lllll}
\hline & \multicolumn{2}{l}{ mRNA expression (fold increase) } & & CsA \\
\cline { 2 - 5 } & Sildenafil & MeP & $1.07 \pm 0.15$ & MPA \\
\hline Hfcm & $0.80 \pm 0.05^{* *}$ & $1.15 \pm 0.72$ & $0.75 \pm 0.14^{*}$ \\
Hfaec & $1.09 \pm 0.35$ & $1.23 \pm 0.79$ & $0.13 \pm 0.1^{*}$ & $0.62 \pm 0.07^{*}$ \\
PBMC & $1.48 \pm 0.37$ & $2.80 \pm 0.65^{*}$ & $0.15 \pm 0.06^{* * *}$ & $1.72 \pm 0.41^{* *}$ \\
\hline
\end{tabular}

mRNA expression specific for CXCL10 in Hfcm, Hfaec and PBMC is depicted after different drug treatments. In Hfcm, sildenafil and MPA significantly inhibited CXCL10 mRNA expression $(0.80 \pm 0.05 * * P<0.01$ and $0.75 \pm 0.14 * P<0.05$ respectively)

In Hfaec, sildenafil did not exert any effect on CXCL10 gene expression; CsA and MPA significantly affected CXCL10 gene expression $(0.73 \pm 0.1 * P<0.05$ and $0.62 \pm 0.07 * P<0.05$ respectively)

In PBMC, sildenafil did not modify CXCL10 gene expression at variance with MeP, CsA, and MPA $(2.80 \pm 0.65 * P<0.05,0.15 \pm 0.06 * * * P<0.001,1.72 \pm$ $0.41 * * P<0.01$ respectively)

Results derive from at least four different cell preparations and are expressed as fold increase vs. IFN $\gamma+$ TNF $\alpha$ - or PHA-induced expression, taken as 1 
(1-specificity, Sp). ROC curve can be assessed by plotting the values of 1-Sp against $\mathrm{Se}$ in a squared box, where the ROC's area under the curve (AUC) is used to measure the performance of a diagnostic test. The AUC lies in the interval 0.5 to 1.0 , so that the greater the area, the better the performance of the variable being examined. A $P$ value less than 0.05 was considered significant.

Sigmoid curves were performed using GraphPad Prism 5 software (GraphPad Software, Inc., La Jolla, CA, USA) and SPSS 12.0 software package (SPSS for Windows 12.0, SPSS Inc., Chicago, IL, USA). The Kolmogorov-Smirnov test for normal distribution of the data, oneway analysis of variance (ANOVA), $t$ test were applied. A $P$ value less than 0.05 was considered significant and corrected for comparison using the Dunnett's or Bonferroni's post hoc test, where appropriate.

Data were expressed as the mean $\pm \mathrm{SE}$.

\section{RESULTS}

\section{Effect of Sildenafil onto CXCL10 Secretion and Gene Expression in Hfcm, Hfaec, and PBMC After Inflammatory Activation}

To verify whether PDE5 inhibition might affect Th1driven inflammatory response at cellular level, the effect of sildenafil onto CXCL10 release has been evaluated in human cardiac, endothelial, and immune cells challenged by maximal inflammatory stimuli in comparison to MeP, CsA, and MPA; drug concentrations have been selected on the basis of the near therapy doses, according to their pharmacokinetics (Cmax and area under the timeconcentration curve, AUC).

In Hfcm (Fig. 1a), sildenafil and MPA significantly inhibited IFN $\gamma+\mathrm{TNF} \alpha$-induced CXCL10 protein secretion $(P<0.01, P<0.001)$; CsA and MeP did not exert any significant effect. Hfcm express PDE5, as shown by western blot analysis (inset of Fig. 1a).

Sildenafil and MeP significantly inhibited IFN $\gamma+$ TNF $\alpha$-induced IL-6 protein secretion $(P<0.001)$, differently from CsA and MPA (Fig. S1 A). Sildenafil did not significantly affect IL-8 protein secretion similarly to MPA, at variance with MeP and CsA $(P<0.001$ and $P<0.05$, respectively, Fig. S1 B).

In Hfaec (Fig. 1b), sildenafil significantly reduced IFN $\gamma+\mathrm{TNF} \alpha$-induced CXCL10 secretion-although to a less extent as compared to $\mathrm{Hfcm}(P<0.05)$ - whereas no effect has been achieved with the other
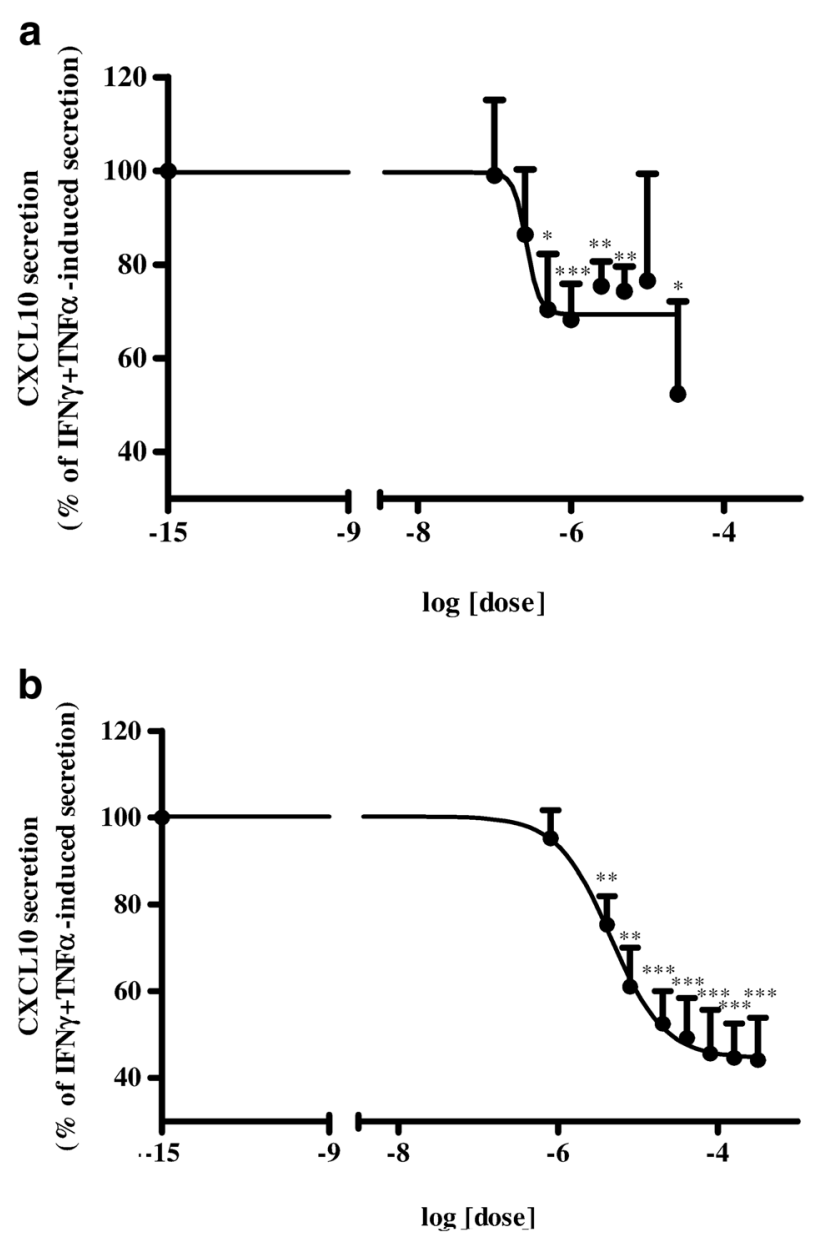

Fig. 2. Sildenafil-induced dose-dependent inhibition of CXCL10 secretion and $\mathrm{IC}_{50}$ calculation in human cardiomyocytes. a Incubation with increasing doses of sildenafil $\left(1 \times 10^{-7}, 2.5 \times 10^{-7}, 5 \times 10^{-7}, 1 \times\right.$ $\left.10^{-6}, 2.5 \times 10^{-6}, 5 \times 10^{-6}, 1 \times 10^{-5}, 2.5 \times 10^{-5} \mathrm{M}\right)$ significantly and dose-dependently reduced CXCL10 protein release, starting from $5 \times 10^{-7} \mathrm{M}$, by $\mathrm{Hfcm}$ stimulated with $\operatorname{IFN} \gamma(1,000 \mathrm{U} / \mathrm{ml})+\mathrm{TNF} \alpha$ $(10 \mathrm{ng} / \mathrm{ml})$. The $\mathrm{IC}_{50}$ was $2.6 \times 10^{-7} \mathrm{M}$. b MPA $\left(8.1 \times 10^{-7}, 4.1 \times\right.$ $10^{-6}, 8.1 \times 10^{-6}, 2.05 \times 10^{-5}, 4.1 \times 10^{-5}, 8.1 \times 10^{-5}, 1.6 \times 10^{-4}, 3.2 \times$ $10^{-4} \mathrm{M}$ ), used for comparison, has been confirmed to induce a dosedependent inhibition of cytokine-induced CXCL10 release by Hfcm, starting from $4.1 \times 10^{-6}$, with an $\mathrm{IC}_{50}=4.6 \times 10^{-6} \mathrm{M}$, similar to sildenafil, although one log higher. Data are derived from six separate experiments using distinct cell preparations. CXCL10 secretion is expressed as percent of IFN $\gamma+\mathrm{TNF} \alpha$-induced secretion (mean $\pm \mathrm{SE}$ ). ${ }^{*} P<0.05 ; * * P<0.01 ; * * * P<0.001$.

immunosuppressants. PDE5 protein expression has been detected in Hfaec (inset of Fig. 1b).

In PBMC, sildenafil did not change PHAinduced CXCL10 release, at variance with the other immunosuppressants $(P<0.01$ and $P<0.001$, Fig. 1c). PBMC express PDE5 protein (inset of Fig. 1c). 


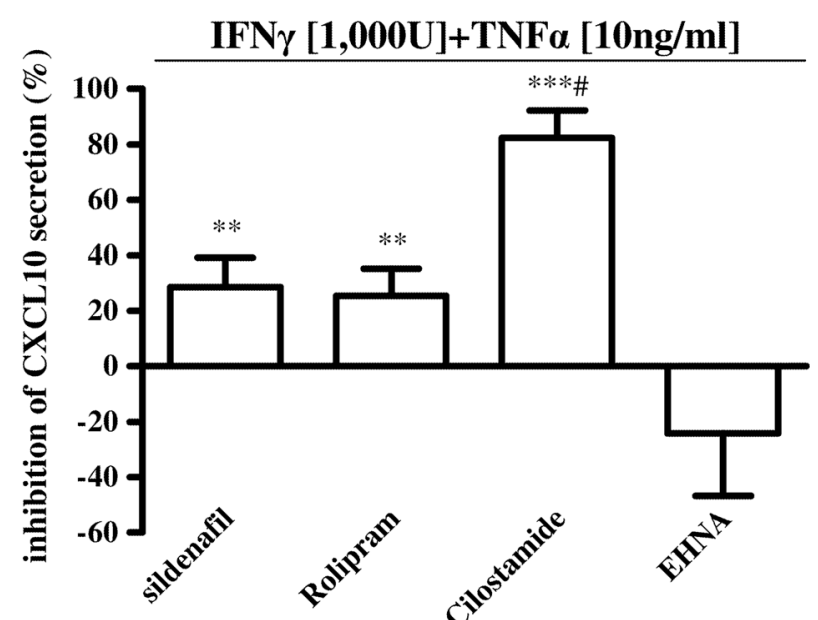

Fig. 3. Effect of different PDE subtype blockage on cytokine-induced CXCL10 release by human cardiomyocytes. The specific blockage for $24 \mathrm{~h}$ of PDE3 activity with cilostamide $(1 \mu \mathrm{M})$ almost blunted IFN $\gamma+$ TNF $\alpha$-induced CXCL10 release by human cardiomyocytes $(82.4 \pm 9.9 \%$ inhibition, ${ }^{* * *} P<0.001,{ }^{\#} P<0.05$ vs. sildenafil treatment); PDE5 and PDE4 inhibition by sildenafil $(1 \mu \mathrm{M})$ and rolipram $(10 \mu \mathrm{M})$, respectively, significantly inhibited CXCL10 secretion $(28.6 \pm 10.7$ and $25.5 \pm 9.8 \%$ inhibition, respectively, $\left.{ }^{* *} P<0.01\right)$; PDE2 blockage with EHNA $(10 \mu \mathrm{M})$ had no significant effect $(-24.0 \pm 22.6 \%$ inhibition). Results (mean \pm SE) are expressed as inhibition of CXCL10 secretion, percent of IFN $\gamma+$ $\mathrm{TNF} \alpha$-induced release, taken as $100 \%$. Data are obtained from experiments with four different cell preparations.

In monocytes sildenafil, CsA and MPA did not exert any significant effect on LPS-induced CXCL10 release, while MeP induced a significant inhibition $(P<0.05$, Fig. S2a). None of the tested drugs affected LPS-induced CXCL10 secretion by macrophages (Fig. S2b).

Monocytes purity was assessed by FACS analysis before and after CD14 magnetic beads separation and was around 10 and $90 \%$ of total cell population, respectively (Fig. S2c, left and right representative panels).

mRNA expression specific for CXCL10 after the different drug treatments has been investigated in each tested cell type and reported in Table 2 and related legend. In particular, sildenafil and MPA significantly inhibited CXCL10 mRNA expression in Hfcm $(P<0.01$ and $P<0.05$, respectively); no significant effect has been observed in Hfaec and in PBMC after sildenafil.

\section{$\mathrm{IC}_{50}$ Determination in $\mathrm{Hfcm}$}

Since sildenafil and MPA exerted a similar inhibitory effect on CXCL10 release in Hfcm, we compared drug potency in vitro in these cells. As we performed doseresponse curves in $\mathrm{Hfcm}$ induced by inflammatory
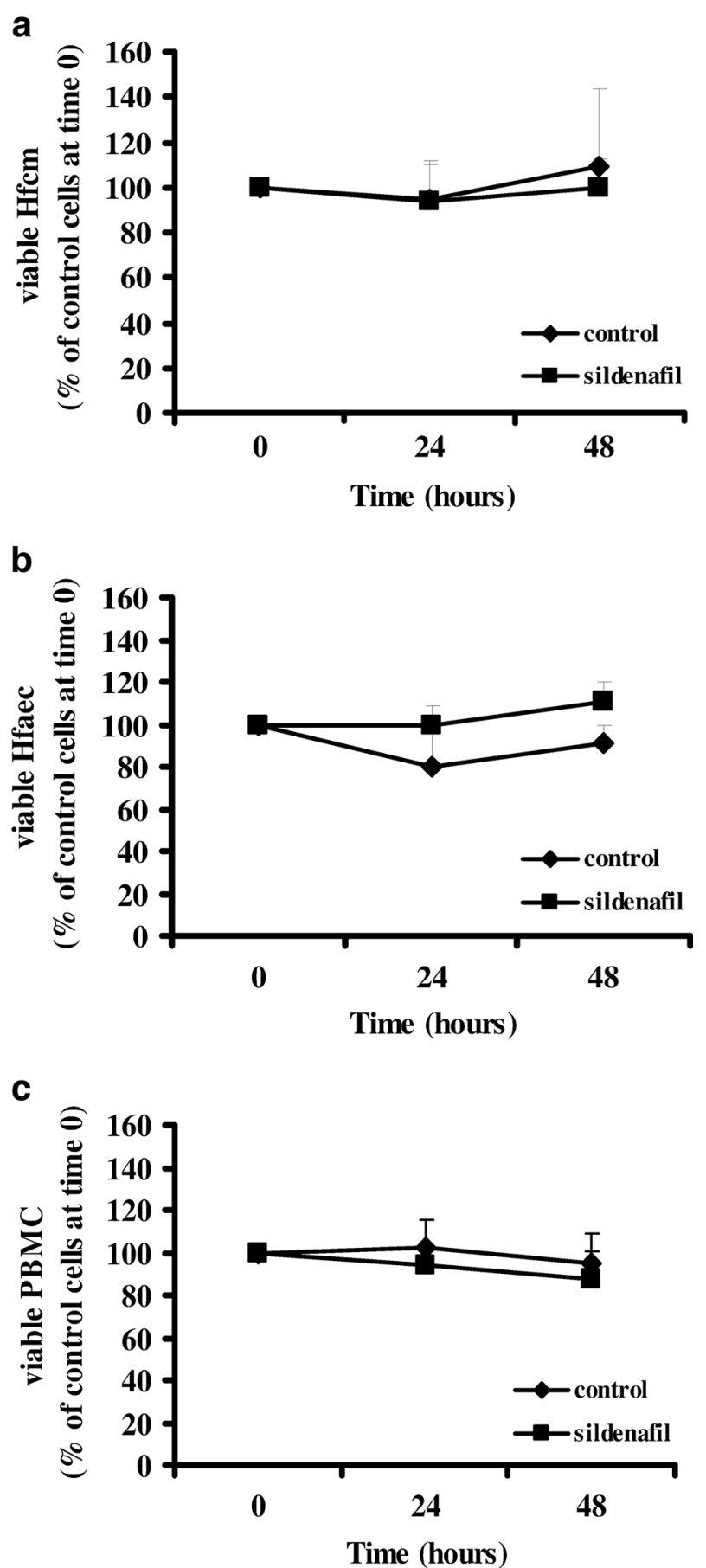

Fig. 4. Effect of sildenafil on human cardiac, endothelial and immune cell viability. a Hfcm cell viability did not change after 24 or $48 \mathrm{~h}$ treatment with sildenafil $(1 \mu \mathrm{M}$, square $)$ vs. control cells (rhombus). b Hfaec viability was unvaried after $24-$ or 48 -h treatment with sildenafil $(1 \mu \mathrm{M}$, square $)$ vs. control cells (rhombus). c. PBMC viability after $24-48 \mathrm{~h}$ did not change with sildenafil $(1 \mu \mathrm{M}$, square) vs. control cells (rhombus). Results derived from at least four different cell preparation for each cell type and are expressed as percent of control cells (taken as $100 \%$ ) at time 0 . 
cytokines and incubated with scalar concentration of sildenafil or MPA, for comparison, we found that sildenafil decreased, in a dose-dependent manner, cytokine-induced CXCL10 secretion, significantly from $5 \times 10^{-7} \mathrm{M}$ $(P<0.05, P<0.01$ or $P<0.001$ vs. IFN $\gamma+\mathrm{TNF} \alpha-$ induced secretion; Fig. 2a). MPA has been confirmed to inhibit CXCL10 secretion dose-dependently (Fig. 2b, $P<0.01, P<0.001$ vs. IFN $\gamma+\mathrm{TNF} \alpha$-induced secretion), as previously shown [34]. The calculated $\mathrm{IC}_{50}$ was $2.6 \times$ $10^{-7} \mathrm{M}$ for sildenafil and $4.6 \times 10^{-6} \mathrm{M}$ for MPA, in line with our previous results [34].

\section{Effect of Sildenafil onto CXCL10 Protein Secretion in Comparison with Other PDE Subtype Blockage in $\mathrm{Hfcm}$}

As we found that human cardiomyocytes were significantly targeted by sildenafil in terms of CXCL10 inhibition at protein and gene level, we compared cytokineinduced CXCL10 release by $\mathrm{Hfcm}$ after PDE subtype 5, 4,3 , and 2 specific blockage (Fig. 3). CXCL10 significantly decreased after PDE5 and PDE4 inhibition by sildenafil and rolipram, respectively $(P<0.01)$. PDE3 inhibition with cilostamide almost abrogated IFN $\gamma+\mathrm{TNF} \alpha$-induced CXCL10 secretion $(P<0.001)$, while PDE2 blockage with EHNA exerted no effect.

\section{Effect of Sildenafil on Hfem, Hfaec, and PBMC Viability}

Sildenafil did not affect Hfcm, Hfaec and PBMC viability after $24-48 \mathrm{~h}$ as compared with control cells, Fig. 4a, b, c.

Fig. 5. Effect of sildenafil on circulating CXCL10 level in diabetic cardiomyopathy. a Receiver operating characteristic (ROC) analysis evidenced that serum CXCL10 $=930 \mathrm{pg} / \mathrm{ml}$ (cut-off value, open circle) had good capability to discriminate subjects who did or did not respond to sildenafil administration, in terms of circulating chemokine decrease. The area under the ROC curve (AUC) resulted 0.80 (95\% confidence interval $=0.584-0.996$, $P<0.01$ ) with a sensitivity of 0.78 and a specificity of 0.69 . b Subjects have been categorized as drug responders (r) and non-responders (nr) to sildenafil treatment. Positive or negative variations in circulating CXCL10 have been observed after sildenafil intake vs. basal level $(504.84 \pm 182.6 \mathrm{pg} / \mathrm{ml}$, $-323.93 \pm 82 \mathrm{pg} / \mathrm{ml})$. Data are expressed as serum CXCL10 change, in picogram per milliliter vs. basal level (mean $\pm \mathrm{SE}) ;(* * P<0.01$, *** $P<0.001$, vs. basal level). $\mathrm{c} \mathrm{r}$ and $\mathrm{nr}$ subgroups showed significant difference in CXCL10 basal level $(1514.92 \pm 221.22 \mathrm{pg} / \mathrm{ml}$ vs. $923.45 \pm$ $76.71 \mathrm{pg} / \mathrm{ml}$, respectively ${ }^{\# \#} P<0.01$ ); CXCL10 level in diabetes (DM, $1719.46 \pm 151.4 \mathrm{pg} / \mathrm{ml}$ ) was similar to basal level in $\mathrm{r}$ subgroup and higher than basal level in nr subgroup ( $\left.{ }^{\# \#} P<0.01\right)$. Subjects with non-diabetic cardiomyopathy (IC) displayed circulating CXCL10 (1186.39 $\pm 162.38 \mathrm{pg}$ / $\mathrm{ml})$ lower than DM and $\mathrm{r}\left({ }^{\circ} \mathrm{P}<0.05\right)$. Data are expressed as basal serum CXCL10 level, in picogram per milliliter (mean $\pm \mathrm{SE}$ ). a

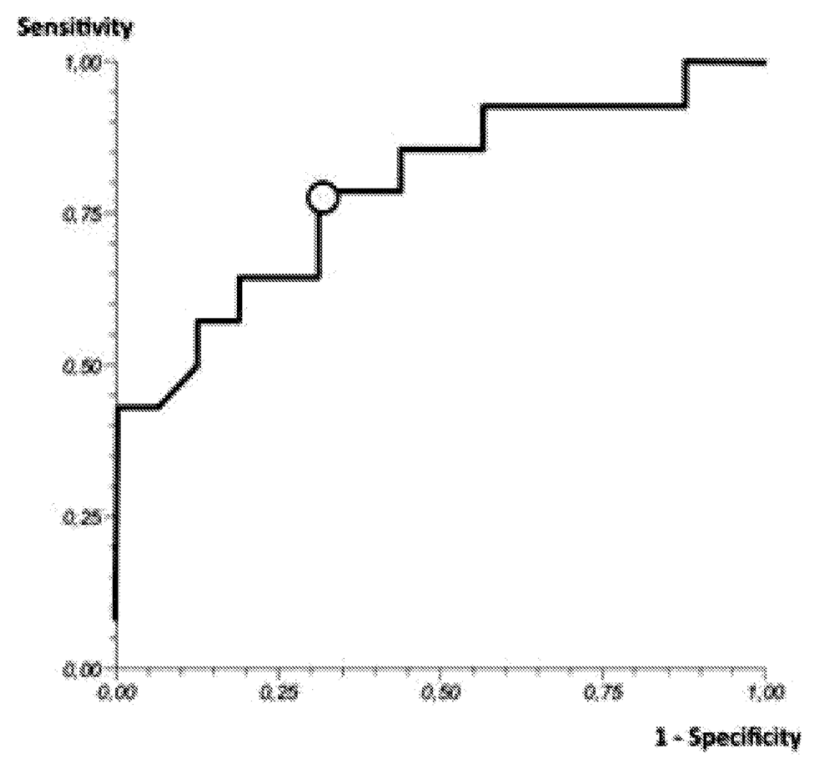

b
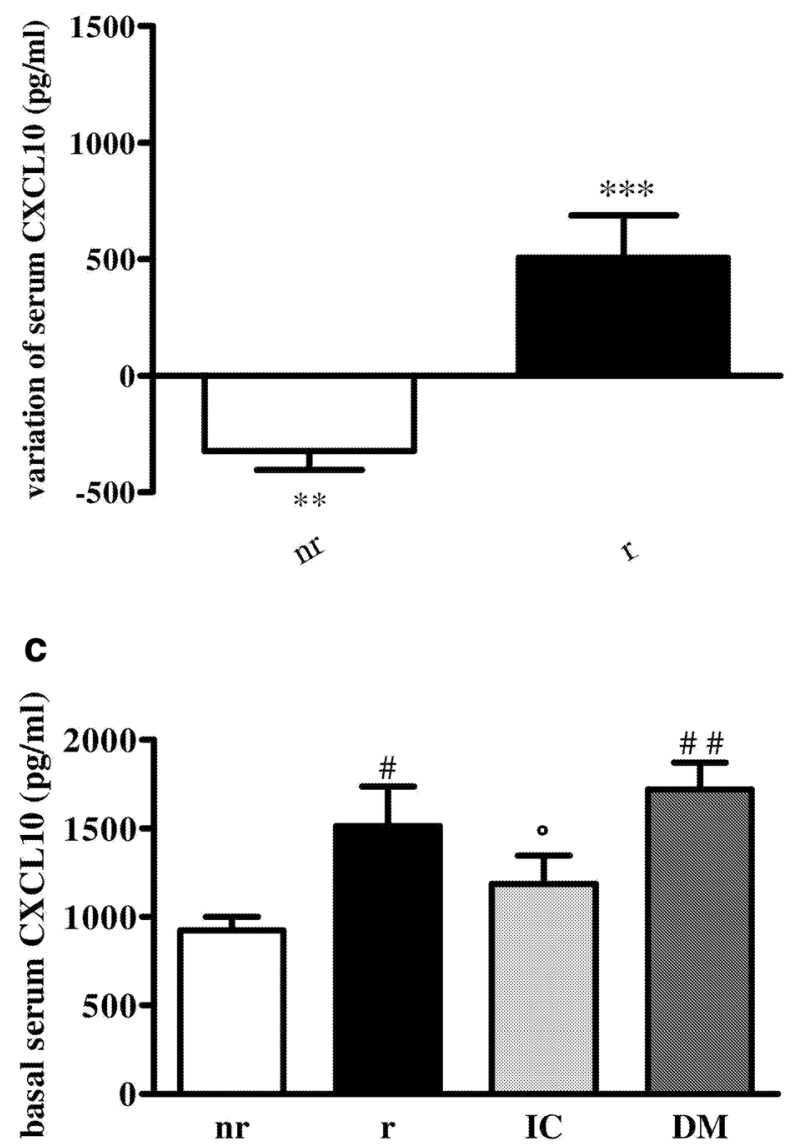


\section{Effect of Sildenafil onto CXCL10 Serum Level in Diabetic Cardiomyopathy}

To verify whether PDE5 inhibition might affect in vivo Th1-associated conditions, we measured CXCL10 level in blood of subjects with diabetic cardiomyopathy before and after sildenafil intake. Receiver operating characteristic (ROC) analysis (Fig. 5a) showed that circulating CXCL10 $=930 \mathrm{pg} / \mathrm{ml}$ is the cut-off value retaining a good ability to discriminate between patients with positive or null/negative response to sildenafil (Fig. 5b): this means that drug intake induced a significant decrease of chemokine level only in subjects with circulating CXCL10 over $930 \mathrm{pg} / \mathrm{ml}$ (positive change, $P<0.001$ ); subjects with CXCL10 below cut-off value showed no change or an increase (null/negative change, $P<0.01$ ) in serum chemokine level; subjects were then defined as (r) responders and non-responders (nr) to sildenafil.

CXCL10 level was significantly different in $\mathrm{r}$ and $\mathrm{nr}$ subgroups $(P<0.01$, Fig. 5c); in particular, r subgroup showed CXCL10 serum level similar to subjects affected by diabetes without sings of cardiac disease (DM), but significantly different from subjects with non-diabetic cardiomyopathy (IC, $P<0.05$ vs. DM and r; Fig. 5c).

\section{DISCUSSION}

The main finding of this study is that sildenafil in human cardiomyocytes inhibited protein and gene expression of IFN $\gamma+\mathrm{TNF} \alpha$-induced chemokine CXCL10 $\left(\mathrm{IC}_{50}\right.$ $2.6 \times 10^{-7} \mathrm{M}$ ), which is a critical trigger of early Th1 immune/inflammatory response during cardiac diseases [12-17]. Sildenafil also significantly reduced inflammatory cytokine-induced IL-6 secretion by Hfcm. Furthermore, sildenafil decreased CXCL10 blood level higher than $930 \mathrm{pg} / \mathrm{ml}$ (cut-off value) in diabetic subjects at cardiomyopathy onset.

Cardiovascular homeostasis is tightly linked to the immune/inflammatory status. Th1-type inflammatory dominance is considered the common link in several comorbid conditions, such as diabetes, atherosclerosis, and heart dysfunction $[1,2]$. A number of Th1-related inflammatory molecules, produced by different tissues and cells, have been shown to widely participate to disease initiation and progression, as well [12-17]. In this scenario, heartrelated studies began to focus on the complex communications between cardiomyocytes and other cells-i.e., endothelial and inflammatory cells recruited to and residing within the heart. Th1-type cytokines and chemokines have been shown to be highly active mediators in cell-to-cell interactions through endocrine, paracrine or autocrine pathways, triggering immune/inflammatory response [6, 9, 37] at disease onset. In particular, previous human in vivo and in vitro studies reported that CXCL10, released by cardiac, endothelial and immune cells challenged by inflammatory conditions could be eligible as reliable marker and therapeutic target at early stages of heart disease, when Th1-type dominance prevails $[12,13,15,20,38]$.

Recently, the use of oral PDE5i to treat different cardiac diseases has been sustained and encouraged by several animal and clinical evidences [23, 31, 37, 39-44]. In particular, sildenafil has been evolving from an antiangina drug to a treatment for ED and, afterward, it has been approved for primary pulmonary hypertension [38, 45-47]. PDE5i beneficial effects seem undoubtedly linked to sildenafil-induced vascular tone regulation: through PDE5 selective inhibition, the release of endogenous cardioprotective molecules (i.e., adenosine and bradykinin) from vascular bed would be promoted, cause/effect relationships in heart tissue accomplished and cardiac cell protection indirectly achieved [48].

In a rat model of pulmonary hypertension, novel mechanisms for sildenafil protection have been shown to relay on preservation of lung morphology, attenuation of inflammatory paths with reduction of several cytokine release, finally ending in a decrease of inflammatory cell infiltration [49].

We provide the first evidence that sildenafil in human cardiomyocytes could counteract CXCL10 protein release with a potency similar to MPA - although with an $\mathrm{IC}_{50}$ of one log lower-and chemokine-specific mRNA expression, as well.

We have previously reported that in Hfcm CXCL10 secretion is mediated by the nuclear transcription factor-kB (NF-kB) and that drug-induced reduction of CXCL10 release by human cardiomyocytes is associated to a block of NF-kB nuclear translocation [20, 38].

We could speculate that in Hfcm sildenafil is able to repress NF-kB activity acting at transcription level via cGMP stabilization, as shown in previous studies [50, 51]; in line with this hypothesis, cGMP level increased in Hfcm after sildenafil, similarly to Hfaec (not shown); our ongoing study aims to clarify those underlying biomolecular mechanism(s).

Conversely, in Hfaec stimulated by proinflammatory cytokines, sildenafil did not affect CXCL10 mRNA expression while chemokine protein release was reduced, albeit to significantly less extent than in $\mathrm{Hfcm}$. In $\mathrm{TNF} \alpha$ stimulated human endothelial cells promoter targeting and 
transcriptional activation of CXCL10 has been shown to depend on NF-kB activation as well [52]. Changes in transcription not always reflect changes in protein expression [53] and differences in protein/mRNA expression may result from gene transcription, specific mRNA stability or translation [54-62]. A deregulation at post-trascriptional level, concerning, i.e., mRNA processing/maturation or stability could result in reduction of translated CXCL10 protein in Hfaec treated with sildenafil [63].

In PHA-activated PBMC sildenafil affected CXCL10 expression neither at protein nor at gene level. Similarly, sildenafil did not exert any significant effect onto CXCL10 released by activated monocytes and macrophages. The lack of significant effects onto immune cells would suggest the exclusion of possible specific modulating effects on immune system by sildenafil.

In this research, we have screened CXCL10 mRNA expression in Hfcm, Hfaec, and PBMC $24 \mathrm{~h}$ after stimulation, at time when the maximal induction of chemokine protein release occurs in all cell types [15]; however, the discrepancy found in CXCL10 protein/mRNA expression after sildenafil in cardiac, endothelial and immune cells cannot exclude some experimental conditions, since incubation/ harvest time could be differentially optimal for mRNA detection depending on different cell types. Our future gene studies will include fine-tuned time-course assays.

Concerning in vivo data, we show that in diabetic cardiomyopathy serum CXCL10 positive or negative variation after sildenafil intake categorized subjects as drug responders vs. non-responders; in fact, as revealed by ROC analysis, CXCL10 serum level equal or higher than cut-off value $(930 \mathrm{pg} / \mathrm{ml})$ is significantly predictive of response to sildenafil. This means that subjects (half number) showing basal circulating CXCL10 level higher than the cut-off value responded to sildenafil treatment with a significant decrease of the chemokine in blood (positive variation); hence, those subjects have been defined as "responders". No decrease in serum chemokine level (null/negative variation) after drug intake has been found in subjects with basal circulating CXCL10 levels lower than $930 \mathrm{pg} / \mathrm{ml}$, and, therefore, named "non-responders".

As we evaluated sex- and age-matched subjects affected by diabetes or cardiomyopathy at the same disease stage as patients with comorbidity, we found that cardiomyopathy per se does not display high systemic CXCL10 with sera values similar to non responders (and healthy subjects, not shown) at variance with diabetes. This latter result could be due to the wide involvement of this chemokine in diabetesassociated vascular bed alterations [37, 64], where CXCL10, among other Th1-type biomediators, is described to be increased (devaraj et al. 2009 cytokine) and responsible for triggering vascular alteration and damage [14, 64].

We could speculate that in some subjects, regardless DM or DM-induced cardiomyopathy, the higher CXCL10 level in blood likely derives from different cell and tissue types and could mirror a wider activation and amplification of the Th1-type response, during which sildenafil seems to be effective while it is neutral when CXCL10 is below the cut-off level, as from our ROC analysis data.

Interestingly, a recent meta-analysis reports that sildenafil causes significant improvements only in subjects with heart failure (HF) and reduced ejection fraction [65] without any beneficial effect in HF subjects with preserved ejection fraction $[66,67]$. So far, it is likely that PDE5 inhibition would be capable to oppose "destabilized" homeostatic conditions with an anti-inflammatory action potentially associated with clinical favorable outcome.

This topic is presently under debate along with the presence of PDE5 expression in heart [66].

A recent study by Degen et al. [68] was unable to detect PDE5 protein expression in tissues from healthy and failing heart of humans and addressed the lack of therapeutic effect of sildenafil in HF-shown by RELAX trial or similar studies [67, 69] - on the basis of PDE5 low level/absence. Nevertheless, PDE5 upregulation has been detected in inflammation-related processes, i.e., oxidative stress and pressure overload hypertrophy [70-74], and would explain the favorable effects on cardiac function achieved by PDE5 inhibition. So far, the current hypothesis is that PDE5 expression is undetectable in normal myocardium, upregulated during hypertrophy and downregulated in end-stage HF [68]. In this light, human heart tissue collection obtained at time of heart transplantation in end-stage HF, when PDE5 expression is downregulated below detection limits, would justify the absence of specific protein signal as shown by Degen et al. [68].

In cell lysates from $\mathrm{Hfcm}$, we have detected PDE5-positive-specific signal, similarly to Hfaec and all immune cell tested by western blot analysis performed with the same antibody reported by Degen et al. [68]. It is possible that specific signal detection could be technically easier using cell lysates from virtually pure culture of human cardiomyocytes, 
which require sample processing different from tissue lysates.

\section{CONCLUSIONS}

The potential advantage of PDE5i use in cardiovascular diseases has been assumed to be based on counteracting some pathophysiologic perturbations, i.e., attenuation of adrenergic stimulation, reduction of ventricular-vascular stiffening and maladaptive chamber remodeling, together with improvement of endothelial function, hemodynamics and enhancement of renal responsiveness [75, 76].

In line with previous data showing that sildenafil is associated with cardioprotection and reduction of multiple circulating inflammatory cytokine levels in Th1-driven conditions [31, 49], herein, we reported that sildenafil reduced high circulating CXCL10, likely deriving from multiple cell types activated during Th1-driven inflammation.

Our results obtained in human cardiomyocytes and endothelial cells suggest that sildenafil can counteract Th1driven processes by targeting CXCL10 at local cellular level.

This observation seems particularly relevant since CXCL10, engaged in cardiac disease onset, is not linked to generic inflammatory status but critically initiates the response to Th1-driven inflammatory challenge and triggers a self-detrimental loop [12-16]. Remarkably, the specific inhibition of PDE3, that is well recognized to retain cardioprotective effects [29], almost blunted CXCL10 secretion by $\mathrm{Hfcm}$ as well. However, it is unlikely that sildenafil effect may be limited to CXCL10; indeed, we might hypothesize that the inhibition of IL- 6 release by human cardiac cells might contribute as well to sildenafilinduced cardioprotective effects. IL-6, as a cardiomyocytederived cytokine, has been shown to start positive feedback circuits and promote cytokine amplification, thereby contributing to chronic inflammatory state establishment [77]. Conversely, our results in human cardiomyocytes on modulation of IL-8 did not evidence significant effects after sildenafil. However, further fine-tuned investigations on possible sildenafil effects onto those and other tissue/ systemic cytokines are necessary, also considering that temporal regulation of those biomediators might result in protective or pathogenic effects, as recently reported for IL6 [78].

Finally, our in vitro and in vivo study present some limitations, i.e., the limited number of biomediators analyzed, or the lack of group of subjects with diabetes mellitus or cardiomyopathy alone treated with sildenafil. In conclusion, albeit we cannot correlate the results obtained in cells and in patients, our data showed that sildenafil targets CXCL10 in Th1-type-dominant conditions and contribute to confirm the anti-inflammatory properties of this drug.

Further in vivo investigations, including a larger number of cytokine types and patients, different stages of cardiomyopathy, longer treatment with sildenafil and follow-up evaluation are mandatory as well as additional in vitro studies on biomolecular mechanism(s) in order to elucidate intracellular target(s) in cell target-based PDE5i pharmacokinetic studies. In light of those preliminary evidences, we speculate that sildenafil could be a new therapeutic option to control cardiomyopathy onset/progression in diabetic subjects while CXCL10 could represent a novel tool to identify patients to treat since early stages.

AUTHOR'S CONTRIBUTION. LDL participated in study design, helped to draft, and revised the manuscript. CC cultured human cells, carried out part of immunoassays, performed data acquisition and analysis. MC performed the majority of the immunoassays and gene analysis. SS performed the statistical analysis and helped to draft and critically revised the manuscript. CA performed in vitro experiments and multiplatform analysis. GBV provided fetal tissues for cell culture and characterization. EG performed clinical study. DG performed clinical study. AMI responsible for the trial NCT00692237 and clinical data, helped to draft the manuscript. SM contributed to data analysis and interpretation, participated in manuscript revision. NP performed in vitro experiments for the isolation of monocyte/macrophage lineage. MF analyzed data from monocyte/macrophage lineage and critically revised the manuscript. AL P.I. of trial NCT00692237 participated in study design and coordination and critically revised the manuscript. $\mathrm{CC}$ conceived and coordinated the study and study design, wrote the manuscript.

\section{COMPLIANCE WITH ETHICAL STANDARDS}

Competing Interests. The authors declare that they have no competing interests.

Sources of Funding. The study was supported by Ministry of Research MIUR Grant FIRB no. RBAP109BLT and RBFR10URHP. 
Open Access This article is distributed under the terms of the Creative Commons Attribution 4.0 International License (http://creativecommons.org/licenses/by/ 4.0/), which permits unrestricted use, distribution, and reproduction in any medium, provided you give appropriate credit to the original author(s) and the source, provide a link to the Creative Commons license, and indicate if changes were made.

\section{REFERENCES}

1. Mann, D.L. 2002. Inflammatory mediators and the failing heart: past, present, and the foreseeable future. Circulation Research 91: 988-98. doi:10.1161/01.RES.0000043825.01705.1B.

2. Fuentes-Antrás, J., A.M. Ioan, J. Tuñón, J. Egido, and Ó. Lorenzo. 2014. Activation of toll-like receptors and inflammasome complexes in the diabetic cardiomyopathy-associated inflammation. International Journal of Endocrinology 2014: 847827. doi:10.1155/2014/ 847827.

3. Esser, N., S. Legrand-Poels, J. Piette, A.J. Scheen, and N. Paquot. 2014. Inflammation as a link between obesity, metabolic syndrome and type 2 diabetes. Diabetes Research and Clinical Practice 105:141-50. doi:10.1016/j.diabres.2014.04.006.

4. Sprague, A.H., and R.A. Khalil. 2009. Inflammatory cytokines in vascular dysfunction and vascular disease. Biochemical Pharmacology 78: 539-52. doi:10.1016/j.bcp.2009.04.029.

5. Gullestad, L., T. Ueland, L.E. Vinge, A. Finsen, A. Yndestad, and P. Aukrust. 2012. Inflammatory cytokines in heart failure: mediators and markers. Cardiology 122: 23-35. doi:10.1159/000338166.

6. Kofler, S., T. Nickel, and M. Weis. 2005. Role of cytokines in cardiovascular diseases: a focus on endothelial responses to inflammation. Clinical Science (London) 108: 205-13. doi:10.1042/CS20040174.

7. Pickup, J.C. 2004. Inflammation and activated innate immunity in the pathogenesis of type 2 diabetes. Diabetes Care 27: 813-23. doi:10.2337/diacare.27.3.813.

8. Striz, I., E. Brabcova, L. Kolesar, and A. Sekerkova. 2014. Cytokine networking of innate immunity cells: a potential target of therapy. Clinical Science (London) 126: 593-612. doi:10.1042/CS20130497.

9. Apostolakis, S., K. Vogiatzi, V. Amanatidou, and D.A. Spandidos. 2009. Interleukin 8 and cardiovascular disease. Cardiovascular Research 84: 353-60. doi:10.1093/cvr/cvp241.

10. Sanchez-Madrid, F., and W.C. Sessa. 2010. Spotlight on mechanisms of vascular inflammation. Cardiovascular Research 86: 171-3. doi:10.1093/cvr/cvq083.

11. Mehra, V.C., V.S. Ramgolam, and J.R. Bender. 2005. Cytokines and cardiovascular disease. Journal of Leukocyte Biology 78: 805-18. doi:10.1189/jlb.0405182.

12. Crescioli, C., A. Buonamano, S. Scolletta, M. Sottili, M. Francalanci, P. Giomarelli, et al. 2009. Predictive role of pretransplant serum CXCL10 for cardiac acute rejection. Transplantation 87: 249-55. doi:10.1097/TP.0b013e3181919f5d.

13. Romagnani, P., and C. Crescioli. 2012. CXCL10: a candidate biomarker in transplantation. Clinica Chimica Acta 413: 136473. doi:10.1016/j.cca.2012.02.009.

14. van den Borne, P., P.H. Quax, I.E. Hoefer, and G. Pasterkamp. 2014. The multifaceted functions of CXCL10 in cardiovascular disease. Biomedical Research International 2014: 893106. doi:10.1155/2014/ 893106.
15. Scolletta, S., A. Buonamano, M. Sottili, P. Giomarelli, B. Biagioli, G.B. Vannelli, et al. 2012. CXCL10 release in cardiopulmonary bypass: an in vivo and in vitro study. Biomedicine and Aging Pathology 2: 187-94. doi:10.1016/j.biomag.2011.07.001.

16. Campbell, J.D., V. Gangur, F.E. Simons, and K.T. HayGlass. 2004. Allergic humans are hyporesponsive to a CXCR3-ligand-mediated Th1 immunity-promoting loop. FASEB 18: 329-31. doi:10.1096/ fj.02-0908fje.

17. Yue, Y., J. Gui, W. Ai, W. Xu, and S. Xiong. 2011. Direct gene transfer with IP-10 mutant ameliorates mouse CVB3-induced myocarditis by blunting Th1 immune responses. PLoS One 6: e18186. doi:10.1371/ journal.pone.0018186.

18. Crescioli, C., M. Sottili, P. Bonini, L. Cosmi, P. Chiarugi, P. Romagnani, et al. 2012. Inflammatory response in human skeletal muscle cells: CXCL10 as a potential therapeutic target. European Journal of Cell Biology 91: 139-49. doi:10.1016/j.ejcb.2011.09.011.

19. Crescioli, C., L. Cosmi, E. Borgogni, V. Santarlasci, S. Gelmini, M. Sottili, et al. 2007. Methimazole inhibits CXC chemokine ligand 10 secretion in human thyrocytes. Journal of Endocrinology 195: 14555. doi: 10.1677/JOE-07-0240.

20. Crescioli, C., R. Squecco, L. Cosmi, M. Sottili, S. Gelmini, E. Borgogni, et al. 2008. Immunosuppression in cardiac graft rejection: a human in vitro model to study the potential use of new immunomodulatory drugs. Experimental Cell Research 314: 1337-50. doi:10.1016/j.yexcr.2007.12.016.

21. Pifarré, P., M. Gutierrez-Mecinas, J. Prado, L. Usero, C. Roura-Mir, M. Giralt, et al. 2014. Phosphodiesterase 5 inhibition at disease onset prevents experimental autoimmune encephalomyelitis progression through immunoregulatory and neuroprotective actions. Experimental Neurology 251: 58-71. doi:10.1016/j.expneurol.2013.10.021.

22. Senzaki, H., C.J. Smith, G.J. Juang, T. Isoda, A. Ohler, N. Paolocci, et al. 2001. Cardiac phosphodiesterase 5 (cGMP specific) modulates beta-adrenergic signaling in vivo and is down-regulated in heart failure. FASEB Journal 15: 1718-26. doi:10.1096/fj.00-0538com.

23. Das, A., L. Xi, and R.C. Kukreja. 2005. Phosphodiesterase-5 inhibitor, sildenafil preconditions adult cardiac myocytes against necrosis and apoptosis: essential role of NO signaling. Journal of Biological Chemistry 280: 12944-55. doi:10.1074/ jbc.M404706200.

24. Kukreja, R.C. 2007. Cardiovascular protection with sildenafil following chronic inhibition of nitric oxide synthase. British Journal of Pharmacology 150: 538-40. doi:10.1038/sj.bjp.0707132.

25. Rossoni, G., B. Manfredi, Colonna V. De Gennaro, M. Berti, M. Guazzi, and F. Berti. 2007. Sildenafil reduces L-NAME-induced severe hypertension and worsening of myocardial ischaemiareperfusion damage in the rat. British Journal of Pharmacology 150: 567-76. doi:10.1038/sj.bjp.0707131.

26. Zahra, G.R., D.F. Elham, A. Atousa, E. Hadi, M. Azadeh, N.O. Seyed, and A. Mohammad. 2007. Protection by cAMP and cGMP phosphodiesterase inhibitors of diazinon-induced hyperglycemia and oxidative/ nitrosative stress in rat Langerhans islets cells: molecular evidence for involvement of non-cholinergic mechanisms. Pesticide Biochemistry and Physiology 87: 261-70. doi:10.1016/ j.pestbp.2006.08.007.

27. Aversa, A. 2010. Systemic and metabolic effects of PDE5-inhibitor drugs. World Journal of Diabetes 1: 3-7. doi:10.4239/wjd.v1.i1.3.

28. Burley, D.S., P. Ferdinandy, and G.F. Baxter. 2007. Cyclic GMP and protein kinase-G in myocardial ischaemia-reperfusion: opportunities and obstacles for survival signaling. British Journal of Pharmacology 152: 855-69. doi:10.1038/sj.bjp.0707409. 
29. Rao, Y.J., and L. Xi. 2009. Pivotal effects of phosphodiesterase inhibitors on myocyte contractility and viability in normal and ischemic hearts. Acta Pharmacologica Sinica 30: 1-24. doi:10.1038/aps.2008.1.

30. Guazzi, M., M. Vicenzi, R. Arena, and M.D. Guazzi. 2011. PDE5 inhibition with sildenafil improves left ventricular diastolic function, cardiac geometry, and clinical status in patients with stable systolic heart failure: results of a 1-year, prospective, randomized, placebo-controlled study. Circulation. Heart Failure 4: 8-17. doi:10.1161/CIRCHEARTFAILURE.110.944694.

31. Giannetta, E., A.M. Isidori, N. Galea, I. Carbone, E. Mandosi, C.D. Vizza, et al. 2012. Chronic inhibition of cGMP phosphodiesterase 5A improves diabetic cardiomyopathy: a randomized, controlled clinical trial using magnetic resonance imaging with myocardial tagging. Circulation 125: 2323-33. doi:10.1161/CIRCULATIONAHA.111.063412.

32. Kukreja, R.C., R. Ockaili, F. Salloum, C. Yin, J. Hawkins, A. Das, and L. Xi. 2004. Cardioprotection with phosphodiesterase-5 inhibition-a novel preconditioning strategy. Journal of Molecular and Cellular Cardiology 36: 165-73. doi:10.1016/j.yjmec.2003.11.001.

33. Netherton, S.J., and D.H. Maurice. 2005. Vascular endothelial cell cyclic nucleotide phosphodiesterases and regulated cell migration: implications in angiogenesis. Molecular Pharmacology 67: 263-72. doi:10.1124/mol.104.004853.

34. Gebska, M.A., B.K. Stevenson, A.R. Hemnes, T.J. Bivalacqua, A. Haile, G.G. Hesketh, et al. 2011. Phosphodiesterase-5A (PDE5A) is localized to the endothelial caveolae and modulates NOS3 activity. Cardiovascular Research 90: 353-63. doi:10.1093/cvr/cvq410.

35. Birks, E.J., P.B. Burton, V. Owen, A.J. Mullen, D. Hunt, N.R. Banner, et al. 2000. Elevated tumor necrosis factor-alpha and interleukin-6 in myocardium and serum of malfunctioning donor hearts. Circulation 102(19 Suppl 3): III352-8.

36. Frangogiannis, N.G. 2004. Chemokines in the ischemic myocardium: from inflammation to fibrosis. Inflammation Research 53: 585-95.

37. Katz, S.D., K. Balidemaj, S. Homma, H. Wu, J. Wang, and S. Maybaum. 2000. Acute type 5 phosphodiesterase inhibition with sildenafil enhances flow-mediated vasodilation in patients with chronic heart failure. Journal of the American College of Cardiology 36: 845-51. doi:10.1016/S0735-1097(00)00790-7.

38. Sottili, M., L. Cosmi, E. Borgogni, E. Sarchielli, L. Maggi, M. Francalanci, et al. 2009. Immunomodulatory effects of BXL-010029, a less hypercalcemic vitamin D analogue, in human cardiomyocytes and T cells. Experimental Cell Research 315: 264 73. doi:10.1016/j.yexcr.2008.10.025.

39. Kass, D.A., H.C. Champion, and J.A. Beavo. 2007. Phosphodiesterase type 5: expanding roles in cardiovascular regulation. Circulation Research 101: 1084-95. doi:10.1161/CIRCRESAHA.107.162511.

40. Kass, D.A. 2012. Cardiac role of cyclic-GMP hydrolyzing phosphodiesterase type 5: from experimental models to clinical trials. Current Heart Failure Reports 9: 192-99. doi:10.1007/s11897-012-0101-0.

41. Bremer, Y.A., F. Salloum, R. Ockaili, E. Chou, W.B. Moskowitz, and R.C. Kukreja. 2005. Sildenafil citrate (Viagra) induces cardioprotective effects after ischemia/reperfusion injury in infant rabbits. Pediatric Research 57: 22-7. doi:10.1203/ 01.PDR.0000147736.27672.15.

42. Nagy, O., A. Hajnal, J.R. Parratt, and V. Agnes. 2004. Sildenafil (Viagra) reduces arrhythmia severity during ischaemia $24 \mathrm{~h}$ after oral administration in dogs. British Journal of Pharmacology 141: 549-51. doi:10.1038/sj.bjp.0705658.

43. Salloum, F.N., Y. Takenoshita, R.A. Ockaili, V.P. Daoud, E. Chou, K. Yoshida, and R.C. Kukreja. 2007. Sildenafil and vardenafil but not nitroglycerin limit myocardial infarction through opening of mitochondrial K(ATP) channels when administered at reperfusion following ischemia in rabbits. Journal of Molecular and Cellular Cardiology 42: 453-8. doi:10.1016/j.yjmcc.2006.10.015.

44. Corinaldesi, C., L. Di Luigi, A. Lenzi, and C. Crescioli. 2016. Phosphodiesterase type 5 inhibitors: back and forward from cardiac indications. Journal of Endocrinological Investigation 39: 143-51. doi:10.1007/s40618-015-0340-5.

45. Ignarro, L.J., P.A. Bush, G.M. Buga, K.S. Wood, J.M. Fukuto, and J. Rajfer. 1990. Nitric oxide and cyclic GMP formation upon electrical field stimulation cause relaxation of corpus cavernosum smooth muscle. Biochemical and Biophysical Research Communications 170: 843-50. doi:10.1016/0006-291X(90)92168-Y.

46. Rajfer, J., W.J. Aronson, P.A. Bush, F.J. Dorey, and L.J. Ignarro. 1992. Nitric oxide as a mediator of relaxation of the corpus cavernosum in response to nonadrenergic, noncholinergic neurotransmission. New England Journal of Medicine 326: 90-94. doi:10.1056/ NEJM199201093260203.

47. Kukreja, R.C., F. Salloum, A. Das, R. Ockaili, C. Yin, Y.A. Bremer, et al. 2005. Pharmacological preconditioning with sildenafil: Basic mechanisms and clinical implications. Vascular Pharmacology 42: 219-32. doi:10.1016/j.vph.2005.02.010.

48. Kukreja, R.C., F.N. Salloum, A. Das, S. Koka, R.A. Ockaili, and L. Xi. 2011. Emerging new uses of phosphodiesterase-5 inhibitors in cardiovascular diseases. Experimental and Clinical Cardiology 16: e30-5.

49. Kiss, T., K. Kovacs, A. Komocsi, A. Tornyos, P. Zalan, B. Sumegi, et al. 2014. Novel mechanisms of sildenafil in pulmonary hypertension involving cytokines/chemokines. MAP kinases and Akt. PLoS One 9: e104890. doi:10.1371/journal.pone.0104890.

50. Vellaichamy, E., N.K. Sommana, and K.N. Pandey. 2005. Reduced cGMP signaling activates NF-kappaB in hypertrophied hearts of mice lacking natriuretic peptide receptor-A. Biochemical and Biophysical Research Communications 327: 106-11. doi:10.1016/ j.bbadis.2009.09.009

51. Katsuyama, K., M. Shichiri, F. Marumo, and Y. Hirata. 1998. NO inhibits cytokine-induced iNOS expression and NF-kappaB activation by interfering with phosphorylation and degradation of IkappaBalpha. Arteriosclerosis, Thrombosis, and Vascular Biology 18: 1796802. doi:10.1161/01.ATV.18.11.1796.

52. Harris, D.P., S. Bandyopadhyay, T.J. Maxwell, B. Willard, and P.E. Di Corleto. 2014. Tumor necrosis factor (TNF)- $\alpha$ induction of CXCL10 in endothelial cells requires protein arginine methyltransferase 5 (PRMT5)-mediated nuclear factor (NF)-KB p65 methylation. Journal of Biological Chemistry 289: 15328-39. doi:10.1074/ jbc.M114.547349.

53. Greenbaum, D., C. Colangelo, K. Williams, and M. Gerstein. 2014. Comparing protein abundance and mRNA expression levels on a genomic scale. Genome Biology 4: 117. doi:10.1186/gb-2003-4-9-117.

54. Fiorentino, D.F., A. Zlotnik, T.R. Mosmann, M. Howard, and A. O'Garra. 1991. IL-10 inhibits cytokine production by activated macrophages. Journal of Immunology 11: 3815. doi:10.1159/000346707.

55. Bogdan, C., J. Paik, Y. Vodovotz, and C. Nathan. 1992. Contrasting mechanisms for suppression of macrophage cytokine release by transforming growth factor- $\beta$ and interleukin-10. Journal of Biological Chemistry 267: 23301.

56. Wang, P., P. Wu, M.I. Siegel, R.W. Egan, and M.M. Billah. 1994. IL10 inhibits transcription of cytokine genes in human peripheral blood mononuclear cells. Journal of Immunology 153: 811.

57. Shrikant, P., E. Weber, T. Jilling, and E.N. Benveniste. 1995. Intercellular adhesion molecule-1 gene expression by glial cells. Differential mechanisms of inhibition by IL-10 and IL-6. Journal of Immunology 155: 1489 .

58. Berkman, N., M. John, G. Roesems, P.J. Jose, P.J. Barnes, and K.F. Chung. 1995. Inhibition of macrophage inflammatory protein- $1 \alpha$ expression by IL-10. Differential sensitivities in human blood 
monocytes and alveolar macrophages. Journal of Immunology 155: 4412. doi:10.1124/jpet.111.180737.

59. Takeshita, S., J.R. Gage, T. Kishimoto, D.L. Vredevoe, and O. Martínez-Maza. 1996. Differential regulation of IL-6 gene transcription and expression by IL-4 and IL-10 in human monocytic cell lines. Journal of Immunology 156: 2591.

60. Song, S., H. Ling-Hu, K.A. Roebuck, M.F. Rabbi, R.P. Donnelly, and A. Finnegan. 1997. Interleukin-10 inhibits interferon- $\gamma$-induced intercellular adhesion molecule-1 gene transcription in human monocytes. Blood 89: 4461

61. Brown, C.Y., C.A. Lagnado, M.A. Vadas, and G.J. Goodall. 1996. Differential regulation of the stability of cytokine mRNAs in lipopolysaccharide-activated blood monocytes in response to interleukin-10. Journal of Biological Chemistry 271: 20108. doi:10.1074/jbc.271.33.20108.

62. Kasama, T., R.M. Strieter, T.J. Standiford, M.D. Burdick, and S.L. Kunkel. 1993. Expression and regulation of human neutrophil-derived macrophage inflammatory protein $1 \alpha$. Journal of Experimental Medicine 178: 63.

63. Tebo, J.M., H.S. Kim, J. Gao, D.A. Armstrong, and T.A. Hamilton. 1998. Interleukin-10 suppresses IP-10 gene transcription by inhibiting the production of class I interferon. Blood 92: 4742-4749. doi:10.1182/blood-2013-03-490961.

64. Antonelli, A., S.M. Ferrari, A. Corrado, E. Ferrannini, and P. Fallahi. 2014. CXCR3, CXCL10 and type 1 diabetes. Cytokine and Growth Factor Reviews 25: 57-65. doi:10.1016/j.cytogfr.2014.01.006.

65. Zhuang, X.D., M. Long, F. Li, X. Hu, X.X. Liao, and Z.M. Du. 2014. PDE5 inhibitor sildenafil in the treatment of heart failure: a metaanalysis of randomized controlled trials. International Journal of Cardiology 172: 581-87. doi:10.1016/j.ijcard.2014.01.102.

66. Redfield, M.M., B.A. Borlaug, G.D. Lewis, S.F. Mohammed, M.J. Semigran, M.M. Lewinter, et al. 2012. Heart Failure Clinical Research Network. PhosphdiesteRasE-5 inhibition to improve clinical status and exercise capacity in diastolic heart failure (RELAX) trial: rationale and design. Circulation. Heart Failure 5: 653-9. doi:10.1161/ CIRCHEARTFAILURE.112.96907.

67. Redfield, M.M., H.H. Chen, B.A. Borlaug, M.J. Semigran, K.L. Lee, G. Lewis, et al. 2013. RELAX Trial. Effect of phosphodiesterase-5 inhibition on exercise capacity and clinical status in heart failure with preserved ejection fraction: a randomized clinical trial. JAMA 309: 1268-1277. doi:10.1001/jama.2013.2024.

68. Degen, C.V., K. Bishu, R. Zakeri, O. Ogut, M.M. Redfield, and F.V. Brozovich. 2015. The emperor's new clothes: PDE5 and the heart. PLoS One 10: e0118664. doi:10.1371/journal.pone.0118664.
69. Andersen, M.J., M. Ersbøll, A. Axelsson, F. Gustafsson, C. Hassager, L. Kober, et al. 2013. Sildenafil and diastolic dysfunction after acute myocardial infarction in patients with preserved ejection fraction: the sildenafil and diastolic dysfunction after acute myocardial infarction (SIDAMI) trial. Circulation 127: 1200-08. doi:10.1161/ CIRCULATIONAHA.112.000056.

70. Takimoto, E., H.C. Champion, M. Li, D. Belardi, S. Ren, E.R. Rodriguez, et al. 2005. Chronic inhibition of cyclic GMP phosphodiesterase $5 \mathrm{~A}$ prevents and reverses cardiac hypertrophy. Nature Medicine 11: 214-22.

71. Nagendran, J., S.L. Archer, D. Soliman, V. Gurtu, R. Moudgil, A. Haromy, et al. 2007. Phosphodiesterase type 5 is highly expressed in the hypertrophied human right ventricle, and acute inhibition of phosphodiesterase type 5 improves contractility. Circulation 116: 238-48. doi: $10.1038 / \mathrm{nm} 1175$.

72. Shan, X., M.P. Quaile, J.K. Monk, B. French, T.P. Cappola, and K.B. Margulies. 2012. Differential expression of PDE5 in failing and nonfailing human myocardium. Circulation. Heart Failure 5: 79-86. doi:10.1161/CIRCHEARTFAILURE.111.961706.

73. Pokreisz, P., S. Vandenwijngaert, V. Bito, A. Van den Bergh, I. Lenaerts, C. Busch, et al. 2009. Ventricular phosphodiesterase-5 expression is increased in patients with advanced heart failure and contributes to adverse ventricular remodeling after myocardial infarction in mice. Circulation 119: 408-16. doi:10.1161/ CIRCULATIONAHA.108.822072.

74. Lu, Z., X. Xu, X. Hu, S. Lee, J.H. Traverse, G. Zhu, J. Fassett, et al. 2010. Oxidative stress regulates left ventricular PDE5 expression in the failing heart. Circulation 121: 1474-83. doi:10.1161/ CIRCULATIONAHA.109.906818.

75. Borlaug, B.A., and W.J. Paulus. 2011. Heart failure with preserved ejection fraction: pathophysiology, diagnosis, and treatment. European Heart Journal 32: 670-9. doi:10.1093/ eurheartj/ehq426.

76. Galie, N., H.A. Ghofrani, A. Torbicki, R.J. Barst, L.J. Rubin, D. Badesch, et al. 2005. Sildenafil citrate therapy for pulmonary arterial hypertension. New England Journal of Medicine 353: 2148-57. doi:10.1056/NEJMoa050010.

77. Ghigo, A., I. Franco, F. Morello, and E. Hirsch. 2014. Myocyte signalling in leucocyte recruitment to the heart. Cardiovascular Research 102: 270-80. doi:10.1093/cvr/cvu030.

78. Fontes, J.A., N.R. Rose, and D. Čiháková. 2015. The varying faces of IL-6: From cardiac protection to cardiac failure. Cytokine 74: 62-8. doi:10.1016/j.cyto.2014.12.024. 